DOI 10.14746/ssp.2021.4.2

\title{
Daniela PASTARMAdZHIEVA
}

University of Plovdiv Paisii Hilendarski, Bulgaria

ORCID ID: 0000-0002-5857-3595

\section{Mina Angelova}

University of Plovdiv Paisii Hilendarski, Bulgaria

ORCID ID: 0000-0002-1094-6356

\section{The Effects of the COVID-19 Pandemic on Trust in the European Union}

\begin{abstract}
At the beginning of 2020, the world faced a new and unexpected challenge. Such a harmful situation has a potential to increase tensions in societies and create citizens' distrust in their own governments and the European Union. In relation to these observations, the main hypothesis assumes that citizens' trust in the Union decreased during the pandemic, compared to previous periods. Thus, the aim of the study is to identify the dynamics of trust in the EU in the member states. The research's object is the citizens of the EU member states and the focus on dynamics in the levels of trust in 2016-2020, measured based on selected indicators. The data for analysis comes from the Eurobarometer. Statistical methods (frequencies and cross tables) and comparative approach are used for the analysis. On the macrolevel, it seemed that European leaders could do better, especially in the initial stages of the COVID-19 pandemic. However, the results of the Eurobarometer survey performed in the summer of 2020 show that average trust in the Union did not decreased. The data shows that there is a variety across the countries, which was not presented in the current study. Thus, a further examination focused on the context in each of the countries is required, namely policies and measures stringency.
\end{abstract}

Key words: trust, pandemic, European Union

\footnotetext{
A the beginning of 2020, the world faced a new and unexpected A challenge. While observing the spread of the disease in China, the European and the other world leaders probably did not expect that it would become a turning point in the history of the world. At that time, it seemed that almost no one believed that the priorities would be changed dramatically, and the daily routines would never be the same as before COVID-19. Thus, no one was prepared for such a course of the events, and the European leaders underestimated the threat. Although they had
} 
time, they got late both with joint decisions and the implementation of measures (Oksanen et al., 2020).

The latter attitude and approach were, to some extent, demonstrated even when Italy became the first and most affected by the COVID-19 European country (Ortenzi, Albanese, Fadda, 2020). The leaders of the EU member states justified their refusal to provide support for Italy by taking care of their own citizens (Herszenhorn, Paun, Deutsch, 2020). Although their argument may sound reasonable in the context of obscurity, it may be grasped as contradictory to the EU's idea of unity and solidarity. The initial months of the pandemic were crucial not only for adopting measures to fight the disease but also for creating a sense of safety and confidence. The societies became tired of the dramatic change in their daily routines alongside various restrictions. Furthermore, adopting measures to overcome the COVID-19 consequences was not a smooth one, and in July 2020, after meeting the Italian prime minister, Angela Merkel stated that the "positions remain apart" (Deutsche Welle, 2020). However, on July 21, 2020, the EU leaders reached an agreement for a recovery plan called Next Generation EU (NGEU) (European Council, 2020).

Such a contradictory situation can increase the tension across the societies and create distrust toward citizens' own governments and the European Union. In relation to the authors' main hypothesis, the trust of the citizens of the EU members states in the Union has decreased during the pandemic compared to previous periods. Thus, the current study aims to identify the dynamics of the trust in the EU across the member states. The object of the research is the citizens of the EU member states, and the focus is the dynamics in the levels of trust in the period 2016-2020, measured on a selection of indicators, namely:

1) Trust in the European Union;

2) Trust in European Parliament;

3) Trust in European Commission;

4) Trust in European Central Bank;

5) The image of the European Union;

6) Assessments of the course of events in the European Union;

7) Satisfaction with the measures taken by the EU institutions against COVID-19;

8) Trust in EU's future decisions on COVID-19 crisis.

The data used is from Eurobarometer, and for the analysis, statistical methods (frequencies and crosstables) and comparative approaches are used. 


\section{Literature review}

In contemporary political science, the significant role of the citizens in the political process was, to a great extent, emphasized by Gabriel Almond and Sydney Verba in their work "The civic culture: Political Attitudes and Democracy in Five Nations." The authors test whether the citizens' attitudes in the examined countries support the democratic political system. They draw attention to the stability of the democracies and how it is associated with the political culture. The political system needs to be following the culture to ensure stability (Almond, Verba, 1989).

The political culture itself consists of various elements, which can be grouped into two main categories - normative elements (political traditions and norms) and axiological elements (political values, political knowledge, political ideas, and ideals) (Blagoeva, 2014). Together with the behavior of the political elites, these elements determine both the general levels of trust in the system as a whole and the trust in a specific situation or toward a specific decision/policy.

Political trust is of rather significance to the political stability and prosperity of the societies (Aksoy et al., 2020). Political trust can be defined as the "belief that the political system or some part of it will produce preferred outcomes even if left untended" (Shi, 2001, p. 401). When speaking of political trust or confidence we usually refer to institutions such as "parliaments, presidents, courts, political parties, and police forces" (Dodsworth, Cheeseman, 2020). If the levels of confidence in the latter are critically low, it is a prerequisite for challenges in the functioning of the political system, may cause instability, and thus the politicians should concern and pay special attention to overcome the situation (Marien, Hooghe, 2011).

As trust is related to the role of citizens, someone may think that trust is relevant only for democracies. Indeed, political trust is different in authoritarian and democratic regimes, but higher levels are found in authoritarian ones (Yang, 2021). It is reasonable as such regimes are more consolidated, and the wide propaganda creates confidence in the political power.

In the context of the COVID-19 pandemic, trust is essential in various ways because it affects policies implementation, but the measures taken by governments also determine it. Furthermore, it is significant for future recovery and development both on national and international levels (Devine et al., 2020). 
Some of the studies focused on the effect of COVID-19 on trust across the EU citizens in institutions concluded that the "pandemic reduces trust in institutions, in particular of those respondents who (rightly) believe that their country is strongly hit by COVID-19" (Aksoy et al., 2020). According to Eurofound, the European Union needs a more holistic approach to overcome the considerably decreased trust of the citizens (Eurofound, 2021). It seems that the current approach is more bureaucratic, and people need more engagement of the institutions with a broader range of issues that they face.

Some authors provide another point of view and see the COVID-19 crisis as a chance for the EU member states with traditionally low levels of trust to act, which can have a "convincing effect" (Brendebach et al., 2020). Such an idea sounds interesting, but it is controversial whether governments that did not create confidence in the citizens in normal situations will have the potential to make it in such challenging circumstances. On the other hand, in some societies, crises may have a consolidating effect, leading to more trust in the authorities.

In the first stage of the pandemic, Shraff (2020) identifies an increase in diffuse political support. His results show that in the Netherlands, the initial lockdown did not result in trust decrease and "that rising COVID-19 numbers lead to increased political trust, while standard determinants of political trust lose relevance in the face of the pandemic" (Schraff, 2020). It seems that the pandemic has the potential to increase trust, and lockdowns do not affect it, but the "direct exposure to COVID-19 reduces trust" (Devine et al., 2020). However, the citizens' higher level of legitimacy given to the governments may be used differently by the authorities as some of them may try to "expand their powers and divide society" (Khemani, 2020).

Speaking of trust in the authorities, we should consider it not an independent variable. The politicians need to make strategies and implement measures and focus on better communicating them with society (Sabat, 2020). Furthermore, the different perceptions of the social groups should also be considered (Bargain, Aminjonov, 2020). Thus, they can produce a stable level of trust and ensure the effectiveness of the measure's implementation.

When examining the association between the measures and trust, we need to consider that not only the measures resulted in trust, but trust if relevant for the effectiveness of the measures. Traditionally societies with a higher level of trust in the institutions tend to follow their regulations. 
It is also demonstrated during the pandemic when "COVID-19 mortality figures have progressed differently in low-trust countries and high-trust countries" (Oksanen et al., 2020) and "higher political trust is associated with a larger reduction in non-essential mobility" (Bargain, Aminjonov, 2020).

\section{Methods and approaches}

For the current study, data from the Eurobarometer was used. The latter consists of the SPSS files of the following studies:

1) Standard Eurobarometer survey 85.2, performed in May 2016;

2) Standard Eurobarometer survey 87.3, performed in May 2017;

3) Standard Eurobarometer survey 89.1, performed in March 2018;

4) Standard Eurobarometer survey 91.2, performed in March 2019;

5) Standard Eurobarometer survey 93.1, performed in July-August 2020.

To test the hypothesis and achieve the research goal, we decided to focus on six of the surveys' questions because we wanted to identify the dynamics in attitudes and trust. Furthermore, as the 2020 survey contains questions focused on the EU response to COVID-19 measures, we processed these data and included the results in the current article. Thus, the examined questions are:

1) Q052 - SE009A: I would like to ask you a question about how much trust you have in certain institutions. For each of the following institutions, please tell me if you tend to trust it or not to trust it (European Parliament). Possible answers: (1) Tend to trust; (2) Tend not to trust. For the current study, we present the share of the respondents who selected the answer to tend to trust.

2) Q064 - SE016: And please tell me if you tend to trust or tend not to trust these European institutions (The European Parliament, The European Commission, The European Central Bank). Possible answers: (1) Tend to trust; (2) Tend not to trust. For the current study, we present the share of the respondents who selected the answer to tend to trust.

3) Q056 - SE010: In general, does the EU conjure up for you a very positive, fairly positive, neutral, fairly negative, or very negative image? Possible answers: (1) Very positive, (2) Fairly positive, (3) Neutral, (4) Fairly negative, and (5) Very negative. For the current study, we present the share of the respondents who selected answers very positive and fairly positive. 
4) Q050 - SE008A: At present, would you say that, in general, things are going in the right direction or the wrong direction in... (the European Union)? Possible answers: (1) Things are going in the right direction, (2) Things are going in the wrong direction. For the current study, we present the share of the respondents who selected answer things are going in the right direction.

5) Q068 - SE019A: In general, how satisfied are you with the measures taken to fight the Coronavirus outbreak by .... (The European Union institutions)? Possible answers: (1) Very satisfied, (2) Fairly satisfied, (3) Rather not satisfied, (4) Not at all satisfied. For the current study, we present the share of the respondents who selected answers very satisfied and fairly satisfied.

6) Q075 - SE023: Thinking about the EU's response to the Coronavirus outbreak, to what extent do you trust or not the EU to make the right decisions in the future? Possible answers: (1) Totally trust, (2) Tend to trust, (3) Tend not to trust, (4) Do not trust at all. For the current study, we present the share of the respondents who selected answers totally trust and tend to trust.

Following the number of cases, only frequencies and cross tables were made using SPSS. Furthermore, a comparative analysis was performed.

\section{Results and discussion}

The results show that the overall average trust in the European Union is relatively stable in the examined period. It varies from $42.1 \%$ to $46.9 \%$. It decreases slightly in 2019, which can result from the BREXIT negotiations. However, it is visible that the highest level of trust is registered in July-August 2020, namely 46.9\%. After the first months of the crisis, this increase in trust presents a positive result of citizens' assessment of the EU's reaction to the COVID-19 outbreak (Figure 1).

Similarly, a slight increase in trust concerns the European Parliament and the European Commission in 2020 compared to 2016. The trust in the European Central Bank is almost unchanged (Figure 2).

Rather interesting is the confidence of the EU citizens in 2020 that things are going in the right direction in the Union. In 2016-2020, the highest share of citizens who share such an opinion was registered in 2020 (36.5\%). In the examined period, it varies from $21.9 \%$ to $36.5 \%$. There is a growing trend from 2016 to 2018 (from $21.9 \%$ to $33.2 \%$ ), but in 2019 the confidence slightly decreased (Figure 3). 
Figure 1. Dynamics in the share of citizens who tend to trust in the European Union, 2016-2020

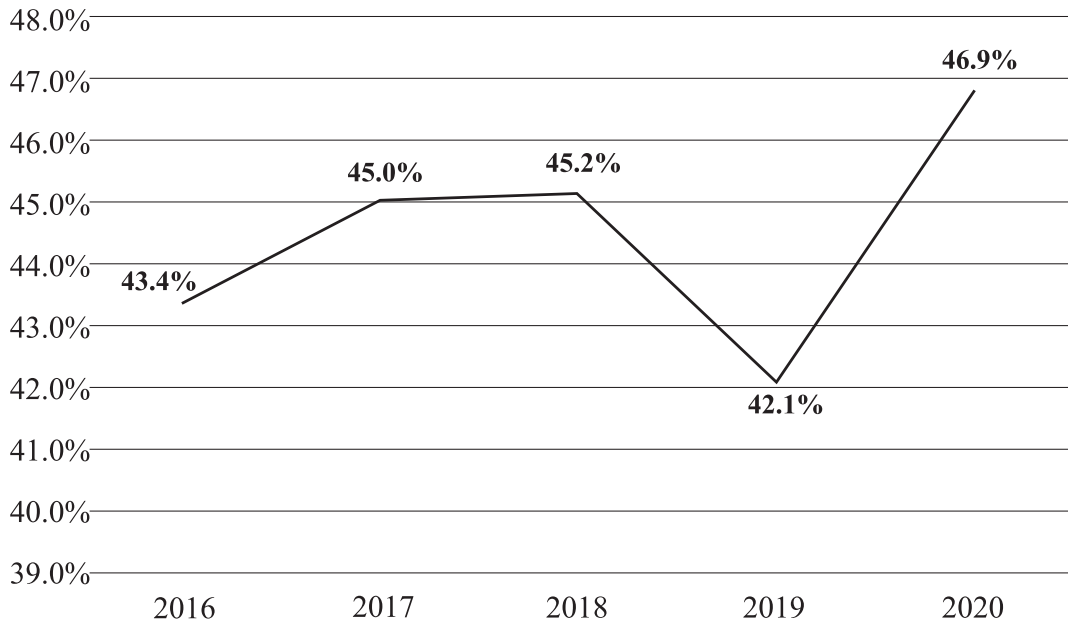

Source: Authors' calculations based on data from Eurobarometer 85.2, 87.3, 89.1, 91.2 and 93.1.

Figure 2. Dynamics in the share of citizens, who trust in European Parliament, European Commission and the European Central Bank, 2016 and 2020

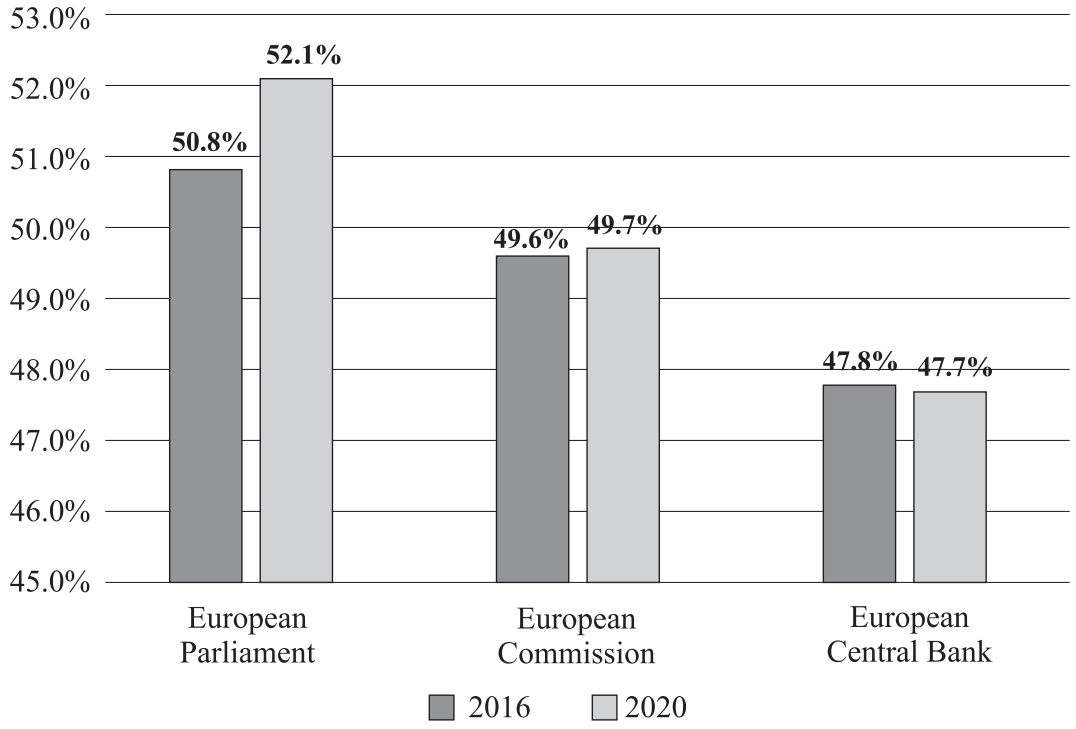

Source: Authors' calculations based on data from Eurobarometer 85.2 and 93.1. 
Figure 3. Dynamics in the share of citizens who believe that things in the $\mathrm{EU}$ are going in the right direction, 2016-2020

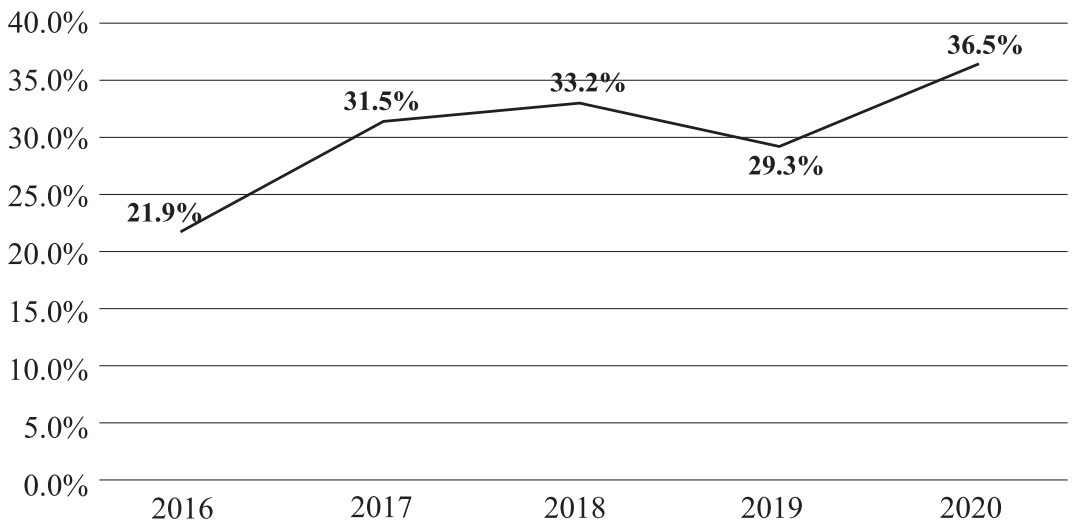

Source: Authors' calculations based on data from Eurobarometer 85.2, 87.3, 89.1, 91.2 and 93.1 .

From 2016 to 2020, the share of the citizens of the EU members states, who determine the image of the EU as rather positive, increased from $34.9 \%$ to $41.3 \%$. In fact, in 2020 compared to 2019 , the increase is almost 1 percent point. This result also indicates that, on the average level, the EU citizens trust in the EU's decisions during the COVID-19 outbreak (Figure 4).

Figure 4. Dynamics in the share of citizens, who would determine the $\mathbf{E U}$ image as rather positive

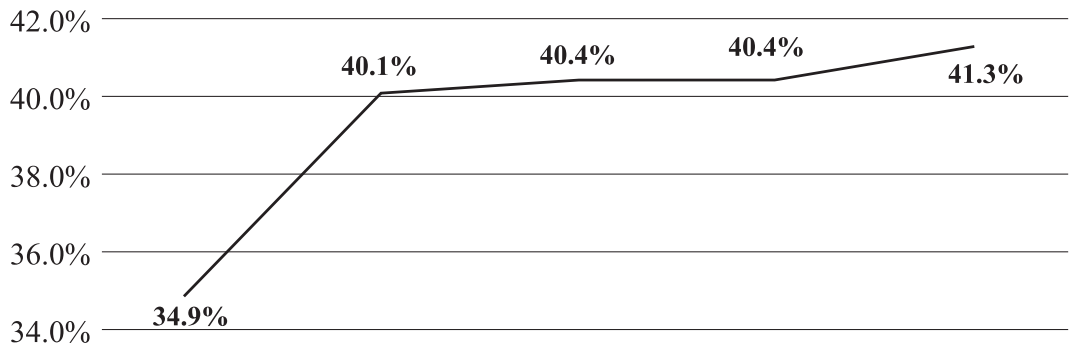

$32.0 \%$

$30.0 \%$

$$
2016
$$

2017

2018

2019

2020

Source: Authors' calculations based on data from Eurobarometer 85.2, 87.3, 89.1, 91.2 and 93.1. 
When the citizens are directly asked about their measures assessments, almost $50 \%$ of them are relatively satisfied. Furthermore, in the summer of 2020, the EU citizens trust that the Union can make the right decisions for overcoming the consequences of the COVID-19 crisis (Figure 5).

\section{Figure 5. Attitudes and trust in EU as concern COVID-19 decisions and measures, 2020}

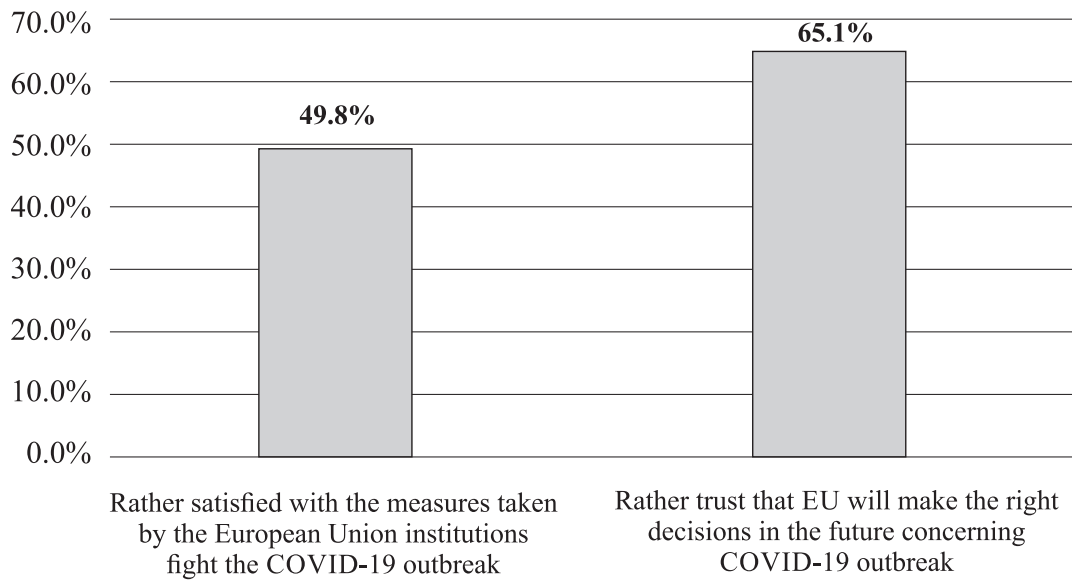

Source: Authors' calculations based on data from Eurobarometer 93.1.

\section{Conclusion}

The relationships between the authorities and the citizens are rather significant for the stability of a political system, and the same is valid for the European Union as well. Especially in a time of crisis, the citizens' trust in those who make the decisions and implement them is crucial to ensure stability and consistency in recovery.

On the macro level, it seemed that the European leaders could do better, especially in the initial stage of the COVID-19 outbreak. There were critics of their reactions, and we expected that this negatively affected the citizens' trust. However, the results of the Eurobarometer survey performed in the summer of 2020 show that the average trust in the Union did not decrease, but stability is identified. Furthermore, it looks that on the average level, there is consolidation, and the citizens trust and rely on the EU to make the right decision to fight the COVID-19 crisis. 
Nevertheless, the data shows a variety across the countries, which was not presented in the current study. Thus, a further examination focused on the context in each country is required, namely policies and stringency of measures. The following stages of the research will consider more indicators and identify statistical correlations. One of the significant associations which need to be studied is between the measures and the trust in EU and national governments.

\section{ACKNOWLEDGEMENT}

The paper is part of project No. KP-06-DK-2/7/2021, funded by the Bulgarian National Science Fund.

\section{Bibliography}

Aksoy C. G., Cabrales A., Dolls M., Windsteiger L. (2020), COVID-19, trust and solidarity in the EU, EconPol Policy Report, no. 27, ifo Institute - Leibniz Institute for Economic Research at the University of Munich, Munich, http:// hdl.handle.net/10419/233530.

Almond G., Verba S. (1989), The Civic Culture: Political Attitudes and Democracy in Five Nations, SAGE, Thousand Oaks.

Bargain O., Aminjonov U. (2020), Trust and compliance to public health policies in times of COVID-19, "Journal of Public Economics", vol. 192, https://doi. org/10.1016/j.jpubeco.2020.104316.

Blagoeva B1. (2014), Political culture and political socialization, in: Fundamentals of political sociology, ed. D. Naneva, UI "Paisii Hilendarski”, Plovdiv.

Brendebach J., Poiares Pessoa Maduro L. M., Tassinari F. (2020), The EU response to the COVID-19 pandemic: achieving relevance, mobilising solidarity and preparing for the future, STG Policy Briefs, http://hdl.handle.net/1814/66789.

Deutsche Welle (2020), Angela Merkel says EU leaders' remain apart'on coronavirus recovery deal, 13.07.2020, https://www.dw.com/en/merkel-eu-recoverydeal/a-54164187.

Devine D., Gaskell J., Jennings W., Stoker J. (2021), Trust and the Coronavirus Pandemic: What are the Consequences of and for Trust? An Early Review of the Literature, "Political Studies Review", vol. 19, no. 2, doi: $10.1177 / 1478929920948684$.

Dodsworth S., Cheeseman N. (2020), Political trust: The glue that keeps democracies together, Westminster Foundation for Democracy, London, https://www.agora-parl.org/sites/default/files/agora-documents/Political\%20trust $\% 20-\% 20$ The $\% 20$ glue $\% 20$ that $\% 20$ keeps\%20democracies\%20together.pdf.

Eurofound (2021), Living, working and COVID-19 (Update April 2021): Mental health and trust decline across EU as pandemic enters another year, Publications Office of the European Union, Luxembourg, doi:10.2806/76802. 
European Commission, Brussels (2017), Eurobarometer 87.3 (2017), GESIS data archive, Cologne. ZA6863 data file version 1.0.0, https://doi.org/ 10.4232/1.12847.

European Commission, Brussels (2018), Eurobarometer 89.1 (2018), GESIS data archive, Cologne. ZA6963 data file version 1.0.0, https://doi.org/ 10.4232/1.13154.

European Commission, Brussels (2019), Eurobarometer 91.2 (2019), GESIS data archive, Cologne. ZA7562 data file version 1.0.0, https://doi.org/ 10.4232/1.13318.

European Commission, Brussels (2020), Eurobarometer 85.2 (2016), GESIS data archive, Cologne. ZA6694 data file version 2.0.0, https://doi.org/ 10.4232/1.13438.

European Commission, Brussels (2021), Eurobarometer 93.1 (2020), GESIS data archive, Cologne. ZA7649 data file version 1.1.0, https://doi.org/ $10.4232 / 1.13696$.

European Council (2021), Special European Council, 17-21 July 2020, https://www. consilium.europa.eu/en/meetings/european-council/2020/07/17-21/.

Herszenhorn D. M., Paun C., Deutsch J. (2020), Europe fails to help Italy in coronavirus fight, "Politico", March 5, 2020, https://www.politico.eu/article/eu-aimsbetter-control-coronavirus-responses/.

Khemani S. (2020), An Opportunity to Build Legitimacy and Trust in Public Institutions in the Time of COVID-19, World Bank, Washington, DC, https://openknowledge.worldbank.org/handle/10986/33715 License: CC BY 3.0 IGO.

Marien S., Hooghe M. (2011), Does political trust matter? An empirical investigation into the relation between political trust and support for law compliance, "European Journal of Political Research", vol. 50, doi: 10.1111/j.14756765.2010.01930.x.

Oksanen A., Kaakinen M., Latikka R., Savolainen I., Savela N., Koivula A. (2020), Regulation and Trust: 3-Month Follow-up Study on COVID-19 Mortality in 25 European Countries, "JMIR Public Health Surveill", vol. 6, no. 2, doi: 10.2196/19218.

Ortenzi F., Albanse E., Fadda M. (2020), A Transdisciplinary Analysis of COVID-19 in Italy: The Most Affected Country in Europe, "Int. J. Environ. Res. Public Health", vol. 17, no. 24, https://doi.org/10.3390/ijerph17249488.

Sabat I., Neuman-Böhme S., Varghese N. E., Barros P. P., Brouwer W., van Exel J., Schreyögg J., Stargardt T. (2020), United but divided: Policy responses and people's perceptions in the EU during the COVID-19 outbreak, "Health Policy", vol. 124, no. 9, https://doi.org/10.1016/j.healthpol.2020.06.009.

Schraff D. (2020), Political trust during the Covid-19 pandemic: Rally around the flag or lockdown effects?, "European Journal of Political Research", https://doi. org/10.1111/1475-6765.12425.

Shi T. (2001), Cultural Values and Political Trust: A Comparison of the People's Republic of China and Taiwan, "Comparative Politics", vol. 33, no. 4, doi: $10.2307 / 422441$. 
Yang H. wen (2021) Comparing the Political Trust and Civic Political Culture of Democracy or Authoritarian in Asian Countries, "International Journal of Research -GRANTHAALAYAH”, vol. 9, no. 2, doi: 10.29121/granthaalayah. v9.12.2021.3491.

\section{Wpływ pandemii COVID-19 na zaufanie do Unii Europejskiej}

\section{Streszczenie}

$\mathrm{Na}$ początku 2020 roku świat zetknął się z nowym i niespodziewanym wyzwaniem. Tak niesprzyjająca sytuacja ma potencjał zwiększenia napięć wśród społeczeństw i budowania sytuacji braku zaufania obywateli wobec własnych rządów i Unii Europejskiej. W odniesieniu do tych obserwacji główna hipoteza badawcza to założenie, że podczas pandemii zmniejszyło się zaufanie obywateli wobec państw członkowskich Unii Europejskiej w stosunku do lat poprzednich. W związku z tym celem badania jest identyfikacja dynamiki zmiany zaufania wobec Unii Europejskiej wśród jej państw członkowskich. Przedmiotem badania są obywatele Unii Europejskiej oraz skupienie na dynamice poziomu zaufania w latach 2016-2020 badane na podstawie wybranych wskaźników. Wykorzystane dane pochodzą z systemu Eurobarometr. Na potrzeby analizy posłużono się metodą analizy statystycznej (częstości i tablic krzyżowych) oraz porównawczej. Wydaje się, że na makropoziomie decydenci europejscy mogli sobie poradzić lepiej, zwłaszcza na wstępnych etapach wybuchu pandemii COVID-19. Wyniki ankiety przeprowadzonej przez Eurobarometr latem 2020 roku pokazują, że sytuacja różni się między państwami, czego jednak nie zaprezentowano w niniejszym badaniu. $\mathrm{Z}$ tego powodu potrzeba dalszych analiz skupionych na kontekście każdego państwa, tj. polityk szczegółowych i poziomu restrykcyjności wykorzystanych środków.

Słowa kluczowe: zaufanie, pandemia, Unia Europejska 